\title{
口腔細菌のアジュバント効果について
}

乾 正 明, 川 越 健一郎, 中 田 洋, 佐 野 茂
吉 川 容, 福 田 富 男, 岡 田 宏
九州大学歯学部歯科保存学第一講座
(指導 青野正男教授)

\section{Adjuvant effects of oral microorganisms on the immunological responses}

M. INUI, K. KAWAGOE, H. NAKATA, S. SANO, Y. YOSHIKAWA, T. FUKUDA and H. OKADA

\author{
(Department of Endodontics and Periodontics, Faculty of \\ Dentistry, Kyushu University, Director : Professor M. AONO)
}

\begin{abstract}
Adjuvant effect of oral microorganisms on the primary immune response to sheep erythrocytes was investigated in $\mathrm{CF}_{1}$ mice by the direct antibody plaque technique at 2, 4 and 6 days after immunization. An adjuvant effect was detected on day 2 with Veillonella alcalescens ATCC 17745, Fusobacterium fusiforme HT-40 and Bacteroides melaninogenicus 32-2 and a weaker effect was found with the same organisms on day 4. Actinomyces viscosus ATCC 15987 showed an adjuvant effect on day 2 only, whilst Streptococcus mutans Ingbritt had no effect at any time. None of the organisms had any effect on the antibody response on day 6. But adjuvant effect of Veillonella to $7 \mathrm{~S}$ antibody production on the primary immune response at 6 days after immunization was detected. Moreover, Veillonella showed an adjuvant effect to $19 \mathrm{~S}$ and $7 \mathrm{~S}$ antibody production on the secondary immune response at 4 days after booster injection. Adjuvant effect on the cellular hypersensitivity to bovine serum albumin was assayed in guinea pigs by skin, corneal and macrophage migration inhibition tests at 3 or 4 weeks after immunization. An enhanced cellular hypersinsitivity was not found with Veillonella, Fusobacterium or Streptococcus. With Bacteroides and Actinomyces an adjuvant effect was detected by skin and corneal tests but not by the migration inhibition test. But with Actinomyces an adjuvant effect on the cellular hypersensitivity was detected by skin, corneal and macrophage migration inhibition tests at 2 weeks after immunization.
\end{abstract}




\section{緒}

歯垢が最も重要な歯肉炎の発病因子と考えられ（Löe Theilade and Jensen, 1965) ${ }^{1)}$, とりわけ歯垢の主体を しめる細菌の発炎機構の解明が重要な研究課題の一つと なっている。従来から細菌の酵素作用 (Tynelius-Bratthall and Attstrom, 1972)2) や peptidoglycan 又は lipopolysaccharide 等の細菌の毒性物質 (Schuster, Hayashi and Bahn, 19673); Snyderman, 19724) 执 び細菌抗原により惹き起こされる免疫反応 (Mergenhagen, Temple and Snyderman, 19705) )が発炎機構とし て重要視され多くの研究報告がなされてきた。

免疫反応による歯周組織の崩壊機構として, 補体の関 与する体液性免疫反応による III型の細胞障害パターン と, 細胞性免疫反応による標的細胞破壊のIV型の細胞障 害パターン (Gell and Coombs, 1964) $)^{6}$ とが考えられ ている (Snyderman, 1973) $)^{7)}$ 。最近になって歯周病患者 において口腔細菌又は歯垢抗原に対する細胞性免疫反応 の成立が健康人に比し有意に高く, その際 lymphotoxin や osteoclast activating factor 等の組織障害因子が産 生されることが明らかになってきた (Ivanyi，Wilton and Lehner, $1972^{8)}$; Horton, Oppenheim and Mergenhagen, $1973^{9)}$; Horton 等 $1972^{10)}$ )。

歯肉溝には色々な抗原性物質が長期に亘り停溜し, 漸 次生体を感作し, 体液性ならびに細胞性免疫反応が成立 し，歯周組織破壊をもたらす可能性は上述の如くであ る。この際, これらの免疫反応が歯肉溝常在細菌が介在 することにより免疫アジュバント効果が発揮されること が考えられる。もしこのアジュバント効果が影響を与え るならば歯周組織破壊の増悪因子としても重要なものと なろう。本論文はこのような観点から口腔細菌の免疫反 応増強効果を検討したものである。

\section{実験材料と方法}

供試菌株: Actinomyces viscosus ATCC 15987, Bacteroides melaninogenicus 32-2, Veillonella alcallescens ATCC 17745, Fusobactrium fusiforme H-T 40, および Streptococcus mutans Ingbritt の 5 種類 の口腔細菌を用いた。

Actinomyces $は$ Brain heart infusion 培地, Bacteroides 1 trypticase-menadione 培地 (Gibbons and Macdonald, 1961) ${ }^{11)}$, Veillonella は Rogosa's V 23
培地 (Rogosa and Bishop, 1964) ${ }^{12}$ ), Fusobacterium は thioglycollate-casitone 培地 (Omata and Disrae1ly, 1956) ${ }^{12)}$, Streptococcus は Todd-Hewit 培地で多 量の純培養を行い, 集菌, Gram 染色を行い他の細菌に よる污染のないことを確認し, 無菌冷生理的食塩水で洗 滌した後, オートクレーブ $\left(120^{\circ} \mathrm{C}, 15\right.$ 分間) で死菌と し, 凍結乾燥して保存した。

$$
\text { アジュバント効果の判定： }
$$

1）体液性免疫反応におけるアジュバント効果の判定 には 6 週令の雄性, $\mathrm{CF}_{1}$ マウスを用いて, 羊血球 (SRB C)の無菌生理的食塩水浮遊液 $0.2 \mathrm{~m} l\left(4 \times 10^{8} \mathrm{SRBC}\right.$ を 含む) を尾静脈より単独又はアジュバント物質（前記供 試菌の凍結乾燥標品 $1 \mathrm{mg}$ ) と同時に注射した。感作後 2 日目 (抗体産生上昇期), 4 日目 (ピーク時)，6日目 (下降期) の一次免疫反応上, 感作後 40 日後に SRBC $\left(4 \times 10^{8}\right.$ 個）を尾静脈より惹起注射し 4 日目の二次免疫 反応における抗体産生を脾細胞 $10^{6}$ 個あたりの溶血斑形 成細胞数 (PFC) で検討し, SRBC 単独注射群とアジュ バント物質同時注射群とで比較し, 抗体産生増強効果 (アジュバント効果) を以下のようにして算定した。

アジュバント比(A.I.) $=\frac{\text { アジュバント添加群の PFC }}{\text { SRBC 単独群の PFC }}$

アジュバント物質としてアジュバント効果の明らかな BCGワクチン(日本 BCG 製造-東京)を positive control として使用し, 供試口腔細菌のアジュバント効果を比較 検討した。

PFC assay には Jerne 直接法 (Jerne and Nordin, 1963) ${ }^{14)}$ 扔よび間接法 (Dresser and Wartis, 1965) ${ }^{15)}$ を用いた。尚この際補体は両法ともモルモット血清（乾 燥補体一東芝化学工業一東京) を, 間接法における抗 IgG 血清は Anti-mouse IgG rabbit serum（医学生物 学研究所一名古屋) を予め至適稀釈倍数を検討の上で利 用した。

2）細胞性免疫反応におけるアジュバント効果の判定 には体重 350 500 g の雄性のハートレー系モルモット を用いて, 皮膚反応, 角膜反応掞よびマクロファージ遊 走阻止試験 (MI 試験) により細胞性免疫反応の成立の 有無を検討した。即ち牛血清アルブミン (BSA, Fraction V; Armour Pharmaceutical Co., Kankakee) 又 は結晶卵白アルブミン（EAc，Armour）を燐酸緩衝生 理的食塩水に $200 \sim 1000 \gamma / \mathrm{m} l$ の割に溶解し， $15,000 \mathrm{r}$. p.m. 90 分間遠沈後孔径 $0.45 \mu$ のミリポアフィルター を通し，等量の下記のアジュバントに油中水型になるよ うによく混和して抗原液とした。 Negative control の 
アジュバントとしてフロインド不完全アジュバント（IC FA, Difco), positive control のアジュバントとして結 核菌体を含んだフロインド完全アジュバント（CFA， Difco), 実験群として供試口腔細菌を $5 \mathrm{mg} / \mathrm{m} l$ の割に 含んだ ICFA を用いた。感作はこれらのアジュバント 加抗原液をモルモットの前後の足蹠と頸部筋肉内に注射 し全量を $1 \mathrm{~m} l$ とした。

蛋白抗原を ICFA に混和して感作する場合, 感作後 3〜14 日に亘り遅延型の皮膚反応，即ち Jones-Mote 型 の反応が成立することがあるので (Bast, Simpson and Dvorak, 1971) ${ }^{16)}$, 本実験では ICFA を negative control のアジュバントとして用いている関係上これを避 ける意味から感作後 2 週目以降に細胞性免疫反応の諸検 討を行った。即ち感作後 2 週目又は $3 \sim 4$ 週目に $10 \gamma$ の BSA（又は EAc）を皮内に注射し，6，24，48 時間後 の発赤径と硬結の程度を測定して (Dupy and Good,

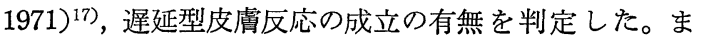
た皮内反応と同時に $10 \mathrm{mg} / \mathrm{m} l$ の BSA（または EAc） を角膜内にごく微量（注射による白濁径が $2 \mathrm{~mm}$ 位） 注射し, 48 時間後の角膜の混濁の程度を観察した（山 村, 1972) ${ }^{18)}$ 。更に数日後に腹腔浸出細胞を利用して毛 細管法によるマクロファージ遊走阻止試験 (MI 試験, David 等, 1964) ${ }^{19)}$ を行い細胞性免疫反応の成立の有無 を検討した。この際腹腔浸出細胞の培養には $56^{\circ} \mathrm{C} 30$ 分 間補体を非働化した正常モルモット血清を $15 \%$ の割に 含む TC-199 培地（千葉血清研究所一千葉）を用いた。 また抗原濃度は BSA, $\mathrm{EAc}$ とも $50 \mu \mathrm{g} / \mathrm{m} l$ とした。腹 腔細胞の遊走阻止率は次のようにして求めた。

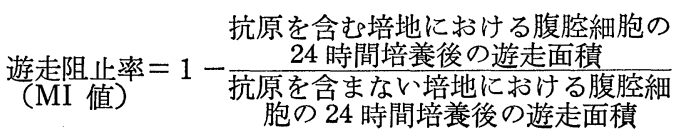

\section{実 験 結 果}

\section{1）体液性免疫反応におけるアジュバント効果}

SRBC $4 \times 10^{8}$ 個の感作による一次免疫反応における $19 \mathrm{~S}$ 抗体産生の増強効果を表 1 に示した。感作後 2 日目 （抗体産生上昇期）において Veillonella, Fusobacterium, Bactroides および Actinomyces はいずれも強い アジュバント効果をもち抗体産生は 4 倍以上に増加され た。これらのアジュバント効果は positive control の BCG のそれよりもはるかに高かった。他方 Streptococcus にはこのようなアジュバント効果は認められなか った。感作後 4 日目 (ピーク時期)になると Veillonella, Fusobacterium および Bacteroides のアジュバント効 果は減少し，A.I. 約 2 を示し BCG のそれとほぼ同等 であった。他方 Actinomyces および Streptococcus にはアジュバント効果は認められなかった。感作後 6 日 目 (下降期) になると BCG および総ての供試口腔細菌 の $19 \mathrm{~S}$ 抗体産生におけるアジュバント効果は認められ なかった。本実験における感作後 6 日目では $19 \mathrm{~S}$ 抗体 産生が急激に減少し，7S 抗体産生がほぼピークに達す る時期と考えられる (Wortis, Tayler and Dresser, 1966 ${ }^{20)}$ ので, 次に $7 \mathrm{~S}$ 抗体産生にお污る増強効果を Veillonella について検討を行った。表 2 に示すように A.I. 1.48 で Veillonella は 7S 抗体についてもアジュ バント効果のあることが判明した。

\begin{tabular}{|c|c|c|c|c|c|c|c|c|c|}
\hline \multirow{2}{*}{$\begin{array}{l}\text { Adjuvant } \\
\text { without }\end{array}$} & \multicolumn{3}{|c|}{ day 2 response } & $\begin{array}{r}\text { day } 4 \mathrm{r} \\
\mathrm{PFC} / 10^{6} \text { cells }\end{array}$ & $\begin{array}{l}\text { spons } \\
\text { S.E. }\end{array}$ & A.I. & $\begin{array}{r}\text { day } \\
\mathrm{PFC} / 10^{6} \mathrm{ce}\end{array}$ & $\begin{array}{l}\text { espon } \\
\pm \text { S.E. }\end{array}$ & A.I. \\
\hline & $5.9 \pm 0.2$ & (20) & 1.00 & $243.1 \pm 24.8$ & $(71)$ & 1.00 & $27.8 \pm 3.1$ & (4) & 1.00 \\
\hline $\mathrm{BCG}$ & $10.5 \pm 1.2$ & (3) & $1.78^{*}$ & $500.5 \pm 80.8$ & (24) & $2.06^{*}$ & $35.6 \pm 2.5$ & (5) & 1.27 \\
\hline Veillonella & $34.6 \pm 3.1$ & (5) & $5.87 *$ & $424.9 \pm 98.1$ & (10) & $1.75^{*}$ & $16.4 \pm 3.4$ & (5) & 0.59 \\
\hline Fusobacterium & $23.1 \pm 3.7$ & (5) & $3.91 *$ & $673.0 \pm 112.5$ & (11) & $2.77^{*}$ & $35.6 \pm 4.5$ & (5) & 1.27 \\
\hline Bacteroides & $43.8 \pm 11.1$ & ( 5$)$ & $7.44^{*}$ & $392.2 \pm 67.1$ & $(10)$ & $1.61^{*}$ & $12.2 \pm 3.4$ & (5) & 0.44 \\
\hline Actinomyces & $40.6 \pm 7.5$ & ( 5) & $6.89 *$ & $225.1 \pm 33.0$ & (10) & 0.93 & $39.2 \pm 6.4$ & (5) & 1.40 \\
\hline Streptococcus & $8.1 \pm 2.3$ & (5) & 1.38 & $222.1 \pm 43.3$ & (4) & 0.91 & $25.4 \pm 3.4$ & (5) & 0.91 \\
\hline
\end{tabular}

表 1 Adjuvant effect on primary immune response in $\mathrm{CF}_{1}$ mice detected by direct $\mathrm{PFC}$ at the various intervals after immunization with $4 \times 10^{8} \mathrm{SRBC}$

( ) : number of experimental animals

* : significantly different from controls receiving no adjuvant $(\mathrm{P}<0.05)$

S.E. : standard errors 
表 2 Adjuvant effect on primary response in $\mathrm{CF}_{1}$ mice detected by indirect $\mathrm{PFC}$ at 6 days after immunization with $4 \times 10^{8} \mathrm{SRBC}$

\begin{tabular}{|c|c|c|c|c|}
\hline Adjuvant & indirect & $\mathrm{PFC} / 10^{6}$ & cells \pm S.E. & A.I. \\
\hline without & & $347 \pm 18$ & (4) & 1.00 \\
\hline Veillonella & & $515 \pm 52$ & (4) & $1.48^{*}$ \\
\hline
\end{tabular}

( ) : number of experimental animals

* : significantly different from control $(\mathrm{P}<0.05)$

SRBC に対する二次免疫反応におけるアジュバント効 果をVeillonella について検討した結果，表 3 に示すよ うに $19 \mathrm{~S}$ および7S 抗体のいずれにおいても A.I. 2.5 でほぼ 2 倍の抗体産生の増加が認められた。

2）細胞性免疫反応におけるアジニバント効果

BSA を抗原として感作後 $3 \sim 4$ 週目にBSA に対する 細胞性免疫反応の成立の有無を検討した結果（表 4 ）, ICFA 群では皮膚反応における発赤の程度は皮内注射 6 時間後が頂点で以後その程度を激减し，48時間後では殆
んど発赤は認められなかった。また硬結反応もなく典型 的な即時型の皮膚反応を示した。更に角膜反応，MI 試 験も陰性で，感作抗原に対する細胞性免疫反応が成立し なかった。一方 CFA 群では，皮膚反応における発赤が 皮内注射 24 時間後で頂点に達し, 48 時間後でも強い発 赤が持続し, 硬結反応も総てに認められ, 明らかな遅延 型皮膚反応を示した。更に角膜反応およびMI 試験も全 例陽性で, 細胞性免疫反応が成立していることが明らか であった。他方実験群中の Veillonella, Fusobacterium および Streptococcus 群では皮膚反応はほぼ ICFA 群 に一致した即時型を示し, 角膜反応および MI 試験も共 に陰性で, 感作抗原に対する細胞性免疫反応の成立は認 められなかった。これに反して Bacteroides および Actinomyces 群では皮膚反応に打ける発赤径は皮内注 射 6 時間後が最高で 24 時間後もその程度は持続し, 48 時間後にはかなり減退した。，更に硬結反応も程度は低い けれども被検 5 例中 Actinomyces 群で 2 例, Bacteroides 群で 1 例に陽性例が認められた。このような例で

表 3 Adjuvant effect on secondary immune response in $\mathrm{CF}_{1}$ mice detected by dir ect or indirect $\mathrm{PFC}$ at 4 days after booster injection with $4 \times 10^{8} \mathrm{SRBC}$

\begin{tabular}{c|cc|cc|c}
\hline Adjuvant & \multicolumn{2}{|c|}{ without } & \multicolumn{2}{|c|}{ Veillooella } & A.I. \\
\hline direct $\mathrm{PFC} / 10^{6}$ cells \pm S.E. & $344 \pm 32$ & (5) & $864 \pm 79$ & (5) & $2.51^{*}$ \\
\hline indirect $\mathrm{PFC} / 10^{6}$ cells \pm S.E. & $845 \pm 64$ & (5) & $2166 \pm 191$ & (5) & $2.56^{*}$ \\
\hline
\end{tabular}

( ) : number of experimental animals

* : significantly different from control $(\mathrm{P}<0.05)$

表 4 Adjuvant effect on cellular hypersensitivity to BSA in guinea pigs detected by skin, corneal and MI tests at 3 or 4 weeks after sensitization

\begin{tabular}{|c|c|c|c|c|c|c|c|c|c|}
\hline \multirow{3}{*}{ Adjuvant } & \multirow{3}{*}{$\begin{array}{l}\text { No. of } \\
\text { animal }\end{array}$} & \multicolumn{5}{|c|}{ Skin response } & \multirow{3}{*}{$\begin{array}{l}\text { Corneal } \\
\text { Response }\end{array}$} & \multirow{3}{*}{\multicolumn{2}{|c|}{ M.I. IS.E. }} \\
\hline & & \multicolumn{3}{|c|}{ Diameter of erythema (mm) } & \multicolumn{2}{|c|}{ Induration } & & & \\
\hline & & $6 \mathrm{hr}$. & $24 \mathrm{hr}$. & $48 \mathrm{hr}$. & $24 \mathrm{hr}$. & $48 \mathrm{hr}$. & & & \\
\hline ICFA & 5 & 14.0 & 7.1 & 2.6 & $(0)$ & (0) & & $0.02 \pm 0.01$ & $(0)$ \\
\hline CFA & 5 & 12.6 & 14.6 & 12.1 & (4) & (5) & (5) $(4) \#$ & $0.47 \pm 0.03$ & $(5)^{*}$ \\
\hline Veillonella & 5 & 12.1 & 6.7 & 2.7 & $(0)$ & (0) & $(0)$ & $0.03 \pm 0.01$ & $(0)$ \\
\hline Fusobacterium & 5 & 13.5 & 6.2 & 4.4 & $(0)$ & (0) & $(0)$ & $0.01 \pm 0.03$ & $(0)$ \\
\hline Bacteroides & 5 & 11.2 & 10.8 & 5.4 & (1) & (1) & (1) (0)\# & $-0.04 \pm 0.03$ & (0) \\
\hline Actinomyces & 5 & 13.1 & 12.0 & 8.2 & (2) & (2) & $(2)(0) \#$ & $-0.04 \pm 0.02$ & $(0)$ \\
\hline Streptococcus & 5 & 16.1 & 9.8 & 2.6 & $(0)$ & (0) & $(0)$ & $-0.02 \pm 0.02$ & $(0)$ \\
\hline
\end{tabular}

( ) : number of animal showing positive reponse

( ) \# : number of animal showing moderate orsever response

* : significantly difference from ICFA $(\mathrm{P}<0.01)$ 
表 5 Adjuvant effect on cellular hypersensitivity to EAc in guinea pigs detected by skin, corneal and $\mathrm{MI}$ tests at 2 weeks after immunization

\begin{tabular}{|c|c|c|c|c|c|c|c|c|}
\hline \multirow{3}{*}{ Adjuvant } & \multirow{3}{*}{$\begin{array}{l}\text { No. of } \\
\text { animal }\end{array}$} & \multicolumn{5}{|c|}{ Skin response } & \multirow{3}{*}{$\begin{array}{l}\text { Corneal } \\
\text { response }\end{array}$} & \multirow{3}{*}{ M.I. \pm S.E. } \\
\hline & & \multicolumn{3}{|c|}{ Diameter of erythema $(\mathrm{mm})$} & \multicolumn{2}{|c|}{ Induration } & & \\
\hline & & $6 \mathrm{hr}$. & $24 \mathrm{hr}$. & $48 \mathrm{hr}$. & $24 \mathrm{hr}$. & $48 \mathrm{hr}$. & & \\
\hline ICFA & 4 & 10.5 & 8.0 & 2.0 & (1) & $(0)$ & $(0)$ & $0.05 \pm 0.10 \quad(0)$ \\
\hline $\mathrm{CFA}$ & 4 & 11.0 & 12.5 & 9.0 & (4) & (4) & (5) $(5) \#$ & $0.34 \pm 0.13 \quad(4)^{*}$ \\
\hline Actinomyces & 5 & 11.2 & 12.6 & 6.6 & (5) & (3) & (5) $(2) \#$ & $0.23 \pm 0.14$ \\
\hline
\end{tabular}

( ) : number of animal showing positive response

( )\#: number of animal showing moderate or severe response

* : significantly different from ICFA $(P<0.02)$

は角膜反応も弱いながら陽性を示した。しかし MI 試験 はいずれにおいても全例陰性であった。即ち典型的では ないが皮膚反応が遅延する傾向を示しかつ角膜反応も陽 性を示したことから,これらの群においては感作抗原に 対する弱い細胞性免疫反応が成立している可能性が推定 されたので次に細胞性免疫反応の検討は感作後 $1 \sim 2$ 週 後に行った方がよいということを考慮して Actinomyces について感作後 2 週目に検討を行った（表 5 )。

ICFA 群では即時型の皮虐反応を示し, 角膜反応およ び MI 試験とも陰性であったが, CFA 群では遅延型皮 膚反応を示し, 角膜反応および MI 試験も陽性であっ た。一方 Actinomyces 群では皮膚反応は遅延し皮内注 射 24 時間後には全例硬結反応が陽性であった。角膜反 応も 5 例中 3 例が強陽性, 2 例が弱い陽性を示した。一 方 MI 試験は 3 例が陽性 (MI : 0.42, 0.29, 0.25) を示 したが 2 例は陰性であった。即ち Actinomyces が細胞 性免疫反応を誘起するアジュバント効果のあることが確 認された。

\section{考察}

Streptococcus mutans 以外の $4 つ$ つ供試口腔細菌に 体液性免疫反応の一次応答に拈ける $19 \mathrm{~S}$ 抗体産生系に おけるアジュバント効果のあること, 更に Veillonella に一次応答における $7 \mathrm{~S}$ 抗体産生系および二次応答にお ける雨抗体産生系に沶けるアジュバント効果のあること が判明した。即ち Actinomyces, Bacteroides, Fusobacterium および Veillonella に一次ならびに二次免疫 反応に扔けるアジュバント効果のあることが推定され た。口腔細菌のアジュバント効果の起因する所要性質に ついては現在不明な点が多いが，アジュバント効果を
示した上記口腔細菌のうち Bacteroides (Hofstad, 1970) ${ }^{21)}$, Fusobacterium (Kristoffersen and Hoftad, 1970)22) および Veillonella (Hofstad and Kristoffersen, 1970) 23) は内毒素を産生し, 内毒素にアジュバント

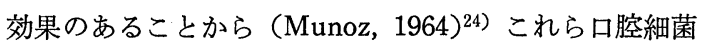
のアジュバント効果は内毒素に起因する可能性を否定す ることは出来ない。歯垢を抗原として惹起された免疫反 応により歯周組織の局所で補体が活性化され歯周組織の 崩壊が生じると考える (Shillitoe and Lehner, 1972 ${ }^{25}$; Snyderman, 1972 $)^{4)}$ 場合, 口腔細菌のアジュバント効 果により免疫反応が増強された結果更に組織崩壊が増強 されるものと推定される。

結核菌体を含む CFA に BSA に対する細胞性免疫反 応を誘起する強いアジュバント効果が本実験においても 確認されたが, Fusobacterium, Streptococcus および Veillonella にはこのようなアジュバント効果は認めら れなかった。他方 Bacteroides および Actinomyces に は皮膚反応と角膜反応において弱いながら細胞性免疫反 応が確認され，このようにアジュバント効果が弱いなが ら存在することが推定された。更に Actinomyces につ き EAc を抗原として追加検討した結果, 明らかに細胞 性免疫反応を誘起するアジュバント効果のあることが判 明した。小谷等も角膜反応を用いて同様の結果を報告し ている (小谷等, 1973) ${ }^{26)}$ 。Horton 等 $(1973)^{8)}$ は歯周 病患者に扮ける蒾垢を抗原とする細胞性免疫反応は他の 系の細胞性免疫反応とは異り非特異的な mitogen に比 較して特異的抗原刺激による場合の方がリンパ球の増殖 (lymphoproliferative response) が著しく低い反面, lymphotoxin の産生においては相違のないことを明ら かにした。即ち歯垢を抗原とする細胞性免疫反応系にお ける細胞障害性が強いことを明らかにし，この可能性の 
一つとして歯垢抗原の特異性に注目している。即ち Chaparas, Thor and Godfrey (1970) ${ }^{27)}$ が Tuberculinactive carbohydrate で同様の結果を報告していること から, 歯垢も carbohydrate-rich な protein-poor な抗 原性状を示すことにより同様の結果を得られたものと推 定している。一方多糖体を CFA に混和して感作した場 合細胞性免疫反応が成立し多糖体が有効な細胞性免疫反 応誘起抗原であることを示した報告 (Gerety, Ferraresi and Raffel, 1970) ${ }^{28)}$ や, 実験動物 (ハムスター) にお ける歯周病発症細菌として Actinomyces viscosus が クローズアップされた (Jordan and Keyes, 1964)29)こ と, 更に本実験の結果から本菌が他の抗原物質に対する 細胞性免疫反応を誘起するアジュバント効果を有してい ること等を考え合せれば, 歯垢抗原に口腔細菌がアジュ バント効果を発揮しその結果細胞性免疫反応が誘起され 歯周組織の崩壊へと発展してゆくという歯周病の一つの 発病機構が推定されよう。

\section{結論}

口腔細菌 (Actinomyces viscosus ATCC 15987, Bacteroides melaninogenicus 32-2, Fusobacterium fusiforme H-T 40, Streptococcus mutans Ingbritt およ び Veillonella alcalescens ATCC 17745 の体液性免疫 反応におけるアジュバント効果を羊血球を抗原としてマ ウスに感作し惹起される一次および二次免疫反応を脾細 胞 $10^{6}$ 個あたりの溶血斑形成細胞数で算定し，その増強 効果を検討した。Streptococcus 以外の 4 つの細菌に一 次免疫反応における $19 \mathrm{~S}$ 抗体産生系に対するアジュバ ント効果のあることが判明した。更にVeillonella につ いて一次免疫反応に怙ける $7 \mathrm{~S}$ 抗体産生系と二次免疫反 応における両抗体産生系に対するアジュバント効果を検 討した結果，いずれにおいてもアジュバント効果のある ことが判明した。

一方これらの口腔細菌の BSA に対する細胞性免疫反 応を誘起するアジュバント効果の有無をモルモット感作 $3 \sim 4$ 週後に皮膚, 角膜, MI 試験等で検討した結果, Fusobacterium, Streptococcus, Veillonella にはこれ らのアジュバント効果はなく, Bacteroides, Actinomyces の数例に皮膚, 角膜反応で細胞性免疫反応成立を認 めたが MI 試験はいずれも陰性であった。そこで更に Actinomyces で EAc を抗原として感作 2 週後に追加 検討した結果, 明らかに細胞性免疫反応の成立を認め Actinomyces に細胞性免疫反応誘起アジュバント効果
があると判定した。

稿を終るに臨み，ご指導とご校閲を賜った青野正男教 授に対し深謝致します。なお細菌を供与していただいた 以下の諸先生に深謝致します。(Bacteroides-東歯大・ 高添一郎教授; Veillonella および Fusobacterium-広 大歯 - 福井一博博士 ; Actinomyces-阪大歯・村山洋二 博士 ; Streptococeus-九大歯・井上昌一博士)

本論文の主旨は第 15 回日本歯周病学会総会 (1972 年 一東京), 第 19 回日本歯科保存学会総会 (1972 年一東 京), 第 2 回日本歯周病学会例会 (1973 年一福岡) およ び第 36 回日本歯科保存学会例会 (1974 年一横須賀) に おいて発表した。

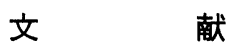

1) Löe, H.E., Theilade, E. and Jensen, S.B. : Experimental gingivitis in man. J. Periodont., $36: 177,1965$.

2) Tynelius-Bratthall, G. and Attström, R. : Acid phosphatase, hyaluronidase and protease in crevices of healthy and chronically inflamed gingiva in dogs. J. Dent. Res. 51 : 279, 1972.

3) Schuster, G.S., Hayashi, J.A. and Bahn, A. N. : Toxic properties of the cell wall of $\mathrm{Gr}$ am-positive bacteria. J. Bact. $93:$ 47, 1967.

4) Snyderman, R. : Role for endotoxin and complement in periodontal tissue destruction. J. Dent. Res. $51: 356,1972$.

5) Mergenhagen, S.E., Tempel, T.S. and Snyderman, R. : Immunologic reactions and periodontal inflammation. J. Dent. Res. 49 : 256, 1970.

6) Gell, P.G.H. and Coombs, R.R.A. : Clinical aspects of immunology. England, 1964, Blackwell Scientific Publications, 320.

7) Snyderman, R. : Immunological mechanisms of periodontal tissue destruction. J. Amer. Dent. Assoc. 87 : 1020, 1973.

8) Ivanyi, L., Wilton, J.M.A. and Lehner, T. : Cell-mediated immunity in periodontal disease : cytotoxicity, migration inhibition and lymphocyte transformation studies. Immunol. 22 : 141, 1972. 
9) Horton, J.E., Oppenheim, J.J. and Mergenhagen, S.E. : Elaboration of lymphotoxin by cultured human peripheral blood leucocytes stimulated with detal-plaque deposits. Clin. exp. Immunol. $13:$ 383, 1973.

10) Horton, J.E. et al. : Bone resorbing activity in supernatant fluid from cultured human peripheral blood leucocytes. Science, 177 : 793, 1972.

11) Gibbons, R.J. and Macdonald, J.B. : Degradation of collagenous substances by Bacteroides melaniogenicus. J. Bact. 81 : 614, 1961.

12) Rogosa, M. and Bishop, F.S. : The genus Veillonella. II. Nutritional studies. J. Bact. $87: 574,1964$.

13) Omata, R.R. and Disraely, M.N. : A selective medium for oral Fusobacteria. J. Bact. $72: 677,1956$.

14) Jerne, N.K. and Nordin, A.A. : Plaque formation in agar by single antibody-producing cells. Science, $140:$ 405, 1963.

15) Dresser, D.W. and Wortis, H.H. : A localized haemolysis in gel method for the detection of cells producing $7 \mathrm{~S}$ antibody. Use of antiglobulin serum to detect cells producing antibody with low haemolytic efficiency. Nature, 208 : 859, 1965.

16) Bast, R.C., Simpson, B.A. and Dvorak, H.F. : Heterogeneity of the cellular immune response. II. The role of adjuvant. Lymphocyte stimulation in cutaneous basophil hypersensitivity. J. exp. Med. 133 : 202, 1971.

17) Dupy, J.M. and Good, R.A. : Passive transfer of delayed hypersensitivity in guineapigs: Role of conventional antibody and antigen. J. Immunol. $106: 528,1971$.

18）山村好弘, 免疫化学 (右田俊介編集). 東京, 1972，中山書店， 254 .

19) David, J.R. et al. : Delayed hypersensitivity in vitro. I. The specificity of inhibition of cell migration by antigen. J. Immunol. 93 : 264,1964

20) Wortis, H.H., Tayler, R.B. and Dresser, D.
W. : Antibody production studied by means of the LHG (localized haemolysis in gel) assay. I. The splenic response of CBA mice to sheep erythrocytes. Immunol. $11: 603$, 1966.

21) Hofstad, T. : Biological activities of endotoxin from Bacteroides melaninogenicus. Archs oral Biol. $15: 343,1970$.

22) Kristoffersen, T. and Hofstad, T. : Chemical composition of lypopolysaccharide endotoxins from human oral Fusobacteria. Archs. oral Biol. 15 : 909, 1970.

23) Hofstad, T. and Kristoffersen, T. : Chemical composition of endotoxin from oral Veillonella. Acta path. microbiol. scand. $78: 760$, 1970 .

24) Munoz, J. : Effect of bacteria and bacterial produdcts on antibody production. Adv. Immunol. 4 : 397, 1964.

25) Shillitoe, E.J. and Lehner, T. : Immunoglobulins and complement in crevicular fluid, serum and saliva in man. Archs. oral Biol. $17: 241,1972$.

26）小谷尚三他．種々のグラム陽性細菌および真菌 細胞壁並びにその水溶性高分子量成分の免疫ア ジュバント活性および多発性関節炎誘起能につ いて．第 3 回日本免疫学会総会記録. p. 267, 1973.

27) Chaparas, S.D. et al. : Tuberculin-active carbohydrate that induces inhibition of macrophage migration but not lymphocyte trans. formation. Science, $170: 637,1970$. (文献 ${ }^{8)}$ より引用)

28) Gerety, R.J., Ferraresi, R.W. and Raffel, S. : Polysaccharide in delayed hypersensitivity. I. Pneumococcal polysacchride as inducer and elicitor of delayed reactivity in guinea pigs. J. exp. Med. 131 : 189, 1970.

29) Jordan, H.V. and Keyes, P.H. : Aerobic, gram-positive, filamentous bacteria as etiologic agents of experimental periodontal disease in hamsters. Archs. oral Biol. 9 : 401, 1964. 